\title{
USE OF PROTECTED METHIONINE (MEPRON M 85) IN CATTLE
}

\author{
J. SCHMIDT* ${ }^{*}$ P. SIPŐCZ, Éva CENKVÁRI and J. SIPŐCZ \\ Department of Animal Nutrition, Pannon Agricultural University, \\ H-9201 Mosonmagyaróvár, Vár 4, Hungary
}

(Received March 22, 1999, accepted June 24, 1999)

\begin{abstract}
The ruminal stability of Mepron M 85 and the effect of supplementation with Mepron M 85 on free methionine level of blood were studied in rumen-fistulated cows and rumen- and duodenum-fistulated growing bulls. In five rumen-fistulated cows in situ $69.5 \%$ and $64.6 \%$ of the methionine content of Mepron M 85 was found after ruminal incubation of $16 \mathrm{~h}$ and $24 \mathrm{~h}$, respectively. Daily rations of the rumenfistulated cows were supplemented with $15.0 \mathrm{~g}$ DL-methionine and $17.7 \mathrm{~g}$ Mepron M 85, which increased the free methionine level of blood from $13.64 \mu \mathrm{mol} / \mathrm{L}$ to 15.35 and $20.46 \mu \mathrm{mol} / \mathrm{L}$, respectively, three hours after feeding. In the four rumenand duodenum-fistulated growing bulls, supplementation with $15.0 \mathrm{~g}$ DL-methionine and $17.7 \mathrm{~g}$ Mepron M 85 increased the total methionine getting into the duodenum during $24 \mathrm{~h}$ from $14.99 \mathrm{~g}$ to 16.84 and $20.84 \mathrm{~g}$, respectively. The influence of Mepron M 85 on milk production was studied in 35 pairs of Hungarian Fleckvieh $\times$ Holstein-Friesian cows. The animals were coupled on the basis of the number of finished lactations, milk production in the previous lactation, and the date of calving. Daily supplementation of $18.0 \mathrm{~g}$ Mepron M 85 increased daily milk production significantly $(\mathrm{p}<0.05)$, by 1.24 litres. Milk fat content also increased significantly (from $3.10 \%$ to $3.19 \%, p<0.05$ ) in the experimental group. The supplementation did not influence milk protein content.
\end{abstract}

Key words: Protected methionine, Mepron M 85, bypass methionine

Microbial protein synthesis in the rumen is of essential importance in the protein and amino acid supply of ruminants, since microbial protein may meet $65-85 \%$ of the protein requirement depending on the production level (Schiemann, 1981). Its precondition is the perfect energy supply of animals, since microbial synthesis is a highly energy-demanding process. According to Hagemeister and Kaufmann (1979), $100 \mathrm{~g}$ organic matter provides energy for the synthesis of $22 \mathrm{~g}$ microbial protein in the rumen. In the nutrient requirements published by ARC (1980) it is supposed that $18.75 \mathrm{~g}$ microbial protein is produced from $100 \mathrm{~g}$ digestible organic matter (DOM). The new Hungarian protein evaluation system (Schmidt et al., 1998) considers that $100 \mathrm{~g}$ fermentable organic matter (FOM) is sufficient for the synthesis of $160 \mathrm{~g}$ microbial protein.

*E-mail: schmidt@movar.pate.hu 
It is known that microbial protein includes less methionine than casein, therefore several scientists consider methionine as the first limiting amino acid for microbial protein synthesis (Fischer, 1972; Schelling et al., 1973; Broderick et al., 1974; Clark, 1975; Schwab et al., 1976; Illg et al., 1987).

In the first third of lactation of high-yielding dairy cows, it often occurs that the energy requirement is not met and that decreases microbial protein production in the rumen. This, together with insufficient methionine supply, can result in the limitation of milk production. Experimental results, which show that DL-methionine administered directly into the abomasum or small intestine and methionine products of low rumen degradability can increase milk production of cows, are explainable (Rogers and McLeay, 1977; Daugaard, 1978; Kaufmann and Lüpping, 1979; Lettner, 1983; Burgstaller et al., 1983a; Leibetseder et al., 1985).

Based upon these facts, some experiments using a bypass methionine product, Mepron M 85, were performed to answer the following questions: (i) How stable is the methionine product Mepron M 85 in the rumen and how much of it can escape from the rumen without degradation? (ii) What kind of effect does Mepron M 85 have on the free methionine level of the blood plasma? (iii) How does Mepron M 85 influence the milk production of dairy cows in the first third of lactation?

\section{Materials and methods}

Mepron M 85 is a bypass methionine product which contains $85 \%$ DLmethionine encapsulated (manufactured by Degussa AG, Hanau, Germany). The ruminal stability of Mepron M 85 was examined in situ in 5 rumen-fistulated dairy cows. The cows were Hungarian Fleckvieh $\times$ Holstein Friesian $\mathrm{R}_{4}$ crosses and were in the last third of lactation. Bags made of Scrynel with a pore diameter of $40 \mu \mathrm{m}$ were used. The incubation periods were $1,2,4,8,12,16$ and $24 \mathrm{~h}$. The ruminal stability of the methionine product was checked three times for each incubation time. After incubation, each bag was washed 8 times for $10 \mathrm{~min}$ with cold tap-water to remove residues of rumen juice. Water was changed after each washing period. Since Mepron M 85 contains only free DL-methionine (and no protein), the methionine left in the bags after incubation was determined with a iodometric method (Degussa Analytik/Analysis, 1986).

The effect of Mepron M 85 on free methionine level of the blood plasma was studied in a periodical trial using 5 dairy cows. The trial included one control and two experimental periods. Each period took 14 days: pre-feeding was of 9 days duration and the measurement period lasted 5 days. Blood samples were taken daily from the jugular vein $3 \mathrm{~h}$ after feeding, as in our experience the methionine content of the blood plasma reaches its peak in the $3^{\text {rd }}$ hour after feeding. Free methionine content of the blood plasma was determined by ion- 
exchange column chromatography using an Aminochrom II amino acid analyser, after protein removal with $60 \%$ perchloric acid, neutralisation with $\mathrm{KOH}$, centrifugation, and uptake in citrate buffer.

\begin{tabular}{|c|c|c|c|}
\hline \multicolumn{4}{|c|}{ Composition of the daily ration of cows: } \\
\hline & $\begin{array}{l}\text { Maize silage } \\
\text { Alfalfa hay } \\
\text { Compound }\end{array}$ & $\begin{array}{r}20.0 \mathrm{~kg} \\
6.0 \mathrm{~kg} \\
5.0 \mathrm{~kg}\end{array}$ & \\
\hline \multicolumn{2}{|l|}{ Composition of the compound: } & \multicolumn{2}{|c|}{ Nutrient content of the daily ration: } \\
\hline Maize & $50.0 \%$ & Dry matter & $14.5 \mathrm{~kg}$ \\
\hline Wheat & $41.0 \%$ & $\mathrm{NE}_{1}$ & $98.1 \mathrm{MJ}$ \\
\hline Soybean meal & $4.0 \%$ & Crude protein & $2100.3 \mathrm{~g}$ \\
\hline Vitamin and minerals premix & $5.0 \%$ & Methionine & $35.6 \mathrm{~g}$ \\
\hline \multirow[t]{5}{*}{ Total } & $100.0 \%$ & Cystine & $27.0 \mathrm{~g}$ \\
\hline & & Crude fibre & $3006.6 \mathrm{~h}$ \\
\hline & & Crude fibre in dry matter & $20.7 \%$ \\
\hline & & $\mathrm{Ca}$ & 135.0 \\
\hline & & $\mathrm{P}$ & 93.6 \\
\hline
\end{tabular}

In experimental periods 1 and 2, $15.0 \mathrm{~g}$ DL-methionine and $17.7 \mathrm{~g} \mathrm{Me}-$ pron $\mathrm{M} 85$, respectively, was mixed to the above ration. In the $1^{\text {st }}$ and $2^{\text {nd }}$ phase of the experiment, the DL-methionine and the Mepron M 85 supplements were mixed into the cows' daily ration and consumed fully by the animals.

The rumen stability of Mepron M 85 was examined also in a periodical trial with 4 rumen- and duodenum-fistulated growing bulls of $550 \pm 12 \mathrm{~kg}$ average body weight. The bulls were Hungarian Fleckvieh $\times$ Holstein Friesian $\mathrm{R}_{4}$ crosses. The trial included one control and two experimental periods. In the two experimental periods, DL-methionine and Mepron M 85 was added to the diet of animals, respectively. Each period lasted for 14 days: pre-feeding was of 11 days duration and the measuring period lasted 3 days. On the first and third days of the measuring period, duodenal chymus was collected for $24 \mathrm{~h}$. During these periods, the quantity of chymus passing through the duodenum in $24 \mathrm{~h}$ was measured via re-entrant cannulas and aliquot samples were taken.

Total methionine content of the chymus was determined by hydrolysis with $6 \mathrm{M}$ hydrochloric acid in a microwave equipment (Milestone MLS-1200 MEGA). The time of hydrolysis was $16 \mathrm{~min}$ and the periods were $1 \mathrm{~min}$ at $250 \mathrm{~W}$ and, after a 1-min interval, $5 \mathrm{~min}$ at $250 \mathrm{~W}$ and at $400 \mathrm{~W}$, respectively, and $4 \mathrm{~min}$ at $650 \mathrm{~W}$. 
Based on the methionine content of samples and the quantity of chymus passing through the duodenum, the amount of methionine getting into the duodenum during $24 \mathrm{~h}$ was calculated.

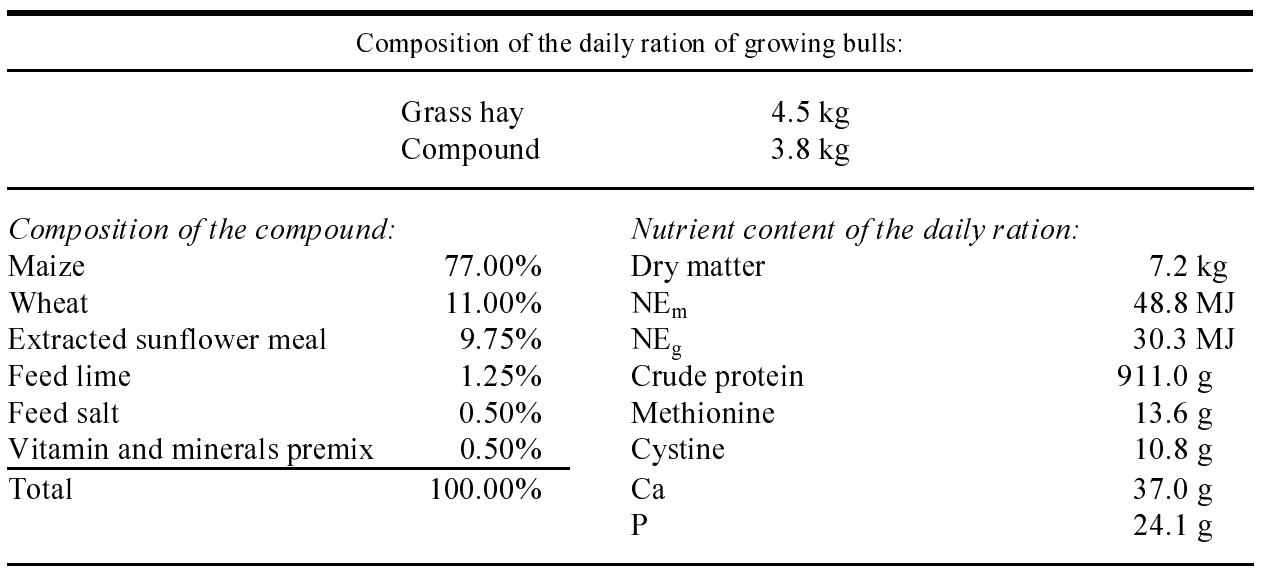

In the experimental periods 1 and 2, $15.0 \mathrm{~g}$ DL-methionine and $17.7 \mathrm{~g}$ Mepron M 85, respectively, was added to the compound.

The effect of Mepron M 85 on milk production was studied with 35 Hungarian Fleckvieh $\times$ Holstein-Friesian cow pairs. The cows were kept in groups. When forming cow pairs, the following aspects were considered: $(i)$ Number of finished lactations; (ii) milk production in the previous lactation; (iii) Days from calving until the start of experiment; (iv) Holstein-Friesian gene ratio; (v) milk production at the beginning of the trial.

The parameters listed above were as follows:

\begin{tabular}{lcc}
\hline & $\begin{array}{c}\text { Experimental } \\
\text { group }\end{array}$ & $\begin{array}{c}\text { Control } \\
\text { group }\end{array}$ \\
\hline Number of the finished lactations & 2.0 & 2.0 \\
Milk production in the previous lactation, $\mathrm{kg}$ & 7715 & 7764 \\
Days from calving until the start of experiment & 33.3 & 35.5 \\
Holstein-Friesian gene ratio, \% & 94.8 & 95.0 \\
Milk production at the beginning of trial, $\mathrm{kg} /$ day & 37.0 & 37.2 \\
\hline
\end{tabular}

The two groups were fed the daily rations shown in Table 1 . 
Table 1

Composition and nutrient content of the daily rations of dairy cows

\begin{tabular}{llrr}
\hline & & Experimental group & Control group \\
\hline Maize silage & $\mathrm{kg}$ & 17.50 & 17.50 \\
Alfalfa haylage & $\mathrm{kg}$ & 3.00 & 2.90 \\
Green alfalfa & $\mathrm{kg}$ & 8.40 & 8.40 \\
Alfalfa hay & $\mathrm{kg}$ & 4.00 & 4.00 \\
Brewer's grains, wet & $\mathrm{kg}$ & 7.00 & 7.00 \\
Barley meal & $\mathrm{kg}$ & 7.30 & 7.30 \\
Premix & $\mathrm{kg}$ & 0.13 & 0.13 \\
Protein compound & $\mathrm{kg}$ & 2.15 & 2.12 \\
& & & \\
Nutrient content of the daily rations: & & 23.74 \\
Dry matter & $\mathrm{kg}$ & 157.68 & 157.31 \\
NE & $\mathrm{MJ}$ & 4136.60 & 4118.60 \\
Crude protein & $\mathrm{g}$ & 57.30 & 57.20 \\
Methionine & $\mathrm{g}$ & 48.70 & 48.60 \\
Cystine & $\mathrm{g}$ & 4406.60 & 4396.30 \\
Crude fibre & $\mathrm{g}$ & 18.50 & 18.50 \\
Crude fibre in dry matter & $\mathrm{g}$ & 172.10 & 171.30 \\
Ca & $\mathrm{g}$ & 85.80 & 85.80 \\
P & $\mathrm{g}$ & & \\
& & &
\end{tabular}

Composition of the protein compound: soybean meal 91.5\%, MCP (mono-calcium phosphate) $2.0 \%$, feed lime $\left(\mathrm{Ca} \mathrm{CO}_{3}\right) 3.0 \%$, salt $2.5 \%$, vitamin and minerals premix $1.0 \%$; total: $100.0 \%$

Cows in the experimental group were fed $18.0 \mathrm{~g}$ Mepron M 85 daily.

The milk production of each group was measured daily and milk composition was determined on the basis of pooled milk of the groups twice a week for 75 days.

Statistical analysis of data was performed by the program Statistica of StatSoft, Inc. (2325 East $13^{\text {th }}$ Street, Tulsa, OK 74104, USA).

\section{Results}

The results of in situ experiments with Mepron M 85 are shown in Table 2.

It can be concluded that methionine loss grew relatively fast in the first $4 \mathrm{~h}$ of incubation and then degradation of Mepron M 85 in the rumen slowed down. Almost half (49.6\%) of the total degradation was measured in the first $4 \mathrm{~h}$ of incubation. After $24 \mathrm{~h}$ of incubation, $64.6 \%$ of the original methionine content was found in Mepron M 85. In reality, probably a larger amount of methionine leaves the rumen without degradation, since feedstuffs do not stay in the rumen for $24 \mathrm{~h}$ in the case of intensive feeding. In general, protected methionine is fed 
to high-yielding dairy cows, especially in the first third of lactation when $8 \%$ of the rumen content escapes per hour because of intensive feeding, so the daily ration stays in the rumen for $12-13 \mathrm{~h}$ in average. Therefore, $78-79 \%$ of the methionine content of Mepron M 85 escapes from the rumen without degradation.

Table 2

Weight and methionine loss of Mepron M 85 in the rumen

\begin{tabular}{crc}
\hline Incubation time, hours & Weight loss, $\%$ & Methionine loss, $\%$ \\
\hline 1 & $8.75 \pm 0.43$ & $7.15 \pm 0.44$ \\
2 & $11.00 \pm 0.60$ & $11.71 \pm 0.71$ \\
4 & $13.28 \pm 0.93$ & $17.57 \pm 1.40$ \\
8 & $16.47 \pm 0.99$ & $18.14 \pm 1.45$ \\
12 & $20.29 \pm 1.52$ & $21.67 \pm 1.90$ \\
16 & $26.44 \pm 1.27$ & $30.55 \pm 2.91$ \\
24 & $29.33 \pm 2.35$ & $35.40 \pm 3.57$ \\
\hline
\end{tabular}

There are various data in the literature about the rumen-stability of different bypass methionine products. In the experiments of Kaufmann and Lüpping (1982), $50-90 \%$ of the methionine content of the studied bypass methionine products was degraded in the rumen. According to the results of Mate (1985), only $20 \%$ of methionine was degraded in the case of hydroxy-methyl-methionine (HMM-Ca) and Ketionin.

The free methionine level of the blood plasma showed that the methionine content of Mepron M 85 indeed escaped from the rumen without degradation and that the coat surrounding methionine granules decomposes in the abomasum and small intestine. Supplementation with $15.0 \mathrm{~g}$ DL-methionine and $17.7 \mathrm{~g}$ Mepron M 85 increased the free methionine level of the blood plasma from $13.64 \mu \mathrm{mol} / \mathrm{L}$ in the control period to $15.35 \mu \mathrm{mol} / \mathrm{L}$ and $20.84 \mu \mathrm{mol} / \mathrm{L}$, respectively. In the case of Mepron M 85, the methionine increment of $50 \%$ was found to be significant $(\mathrm{p}<0.01)$. Like in this study, supplementation with bypass methionine (HMM-Ca) increased free methionine content of the blood in the experiments of Koch and Tanner (1981) and Spiekers (1988) as well. Hagemeister (1984) found that feeding $45 \mathrm{~g}$ bypass methionine increased free methionine content of blood at the same rate as did $15 \mathrm{~g}$ DL-methionine infused into the abomasum.

The assumption about the strong protection of Mepron M 85 is supported also by the results of trials conducted with growing cattle (Table 3 ). When the daily ration was supplemented with $15 \mathrm{~g}$ DL-methionine, the amount of methionine getting into the duodenum increased by $1.85 \mathrm{~g}(12.3 \%)$ in $24 \mathrm{~h}$ as compared to the control period. This showed that methionine was not degraded completely in the rumen. Kaufmann and Lüpping (1982) also found that $95 \%$ of DL-methionine supplementation became 
degraded in the rumen. Addition of $17.7 \mathrm{~g}$ Mepron increased the quantity of methionine getting into the small intestine by $5.85 \mathrm{~g}(39.0 \%)$, which increase was significant. It is less than that was suspected on the basis of the in situ results.

Table 3

Effect of addition of DL-methionine and Mepron M 85

\begin{tabular}{lccc}
\hline Period & $\begin{array}{c}\text { Dry matter getting } \\
\text { into the duodenum } \\
\mathrm{g} / 24 \mathrm{~h}\end{array}$ & $\begin{array}{c}\text { Methionine content } \\
\text { of chymus } \\
\mathrm{g} / \mathrm{kg} \text { dry matter }\end{array}$ & $\begin{array}{c}\text { Methionine getting } \\
\text { into the duodenum } \\
\mathrm{g} / 24 \mathrm{~h}\end{array}$ \\
\hline Control & $4745.08 \pm 1875.6$ & $3.16 \pm 0.22$ & $14.99 \pm 5.61$ \\
DL-methionine & $4784.06 \pm 1762.7$ & $3.52 \pm 0.39$ & $16.84 \pm 5.51$ \\
Mepron M 85 & $4974.94 \pm 1575.6$ & $4.19 \pm 0.38$ & $20.84 \pm 4.97$ \\
\hline
\end{tabular}

This can be explained by the following factors: $(i)$ In growing cattle, as a result of the less intensive feeding only $4-5 \%$, rather than $8 \%$, of the feed escaped from the rumen per hour. Therefore, the feed stayed in the rumen for 20 $24 \mathrm{~h}$ instead of 12-13 h, which increased methionine loss from the bypass product. (ii) It is possible that in the first part of the duodenum (at the site of the cannula) only a part of the protected methionine was present in the chymus because the coating of the M 85 granule had not been fully decomposed in the abomasum. Although the difference between methionine losses, detected in situ and in vivo, can be explained mainly by the less intensive feeding of growing cattle, the second factor cannot be excluded either.

Our results coincide with those of Langar et al. (1978) who found 9-54\% of methionine in the duodenum when bypass methionine (n-stearoyl-DLmethionine) was fed, depending on the type and dose of product.

The results of the field trial are shown in Table 4. It can be concluded that during the 75 days of the trial $18 \mathrm{~g}$ Mepron M 85 increased daily milk production of the experimental group by $1.24 \mathrm{~kg}$ on the average $(\mathrm{p}<0.05)$. These results coincide with the findings of other authors. Increase of milk production has been reported as an effect of supplementation with Mepron (Kaufmann and Lüpping, 1979; Leibetseder et al., 1985; Günther and Hagena, 1987; Spiekers, 1988). Feeding of other bypass methionine products also increased milk production (Journet and Hoden, 1980; Sprondly, 1981; Küther, 1982; Yang et al., 1986).

Although fat content of milk was higher in the experimental group than in the control one, the difference did not prove to be significant. At the same time, some authors reported an increase of milk fat content after addition of bypass methionine (Burgstaller et al., 1983a; Günther and Hagena, 1987). Feeding of Mepron M 85 did not influence milk protein content. Because of higher milk produc- 
tion, milk fat and milk protein production also increased in the experimental group. For milk fat, the increase was significant $(\mathrm{p}<0.05)$.

There are some reports on the increase of milk fat content as the effect of feeding bypass methionine (Burgstaller, 1983a, $b$; Hagena, 1985; Lettner, 1983). In a previous experiment conducted by us, feeding of HMM-Ca increased not only daily milk fat production but milk fat content as well (Schmidt et al., 1987).

Table 4

Effect of Mepron M 85 on milk production and milk composition

\begin{tabular}{lccc}
\hline & & Experimental group & Control group \\
\hline Milk production & $\mathrm{kg}$ & $34.93^{\mathrm{a}} \pm 2.25$ & $33.69^{\mathrm{b}} \pm 2.38$ \\
Milk composition & & & \\
Dry matter & $\%$ & $11.23 \pm 0.37$ & $11.15 \pm 0.44$ \\
Fat & $\%$ & $3.19 \pm 0.19$ & $3.10 \pm 0.23$ \\
Protein & $\%$ & $2.96 \pm 0.10$ & $2.96 \pm 0.10$ \\
Daily production by & milk & & \\
Dry matter & $\mathrm{kg} /$ day & $3.94 \pm 0.20$ & $3.78 \pm 0.21$ \\
Fat & $\mathrm{kg} /$ day & $1.12^{\mathrm{a}} \pm 0.06$ & $1.05^{\mathrm{b}} \pm 0.07$ \\
Protein & $\mathrm{kg} /$ day & $1.04 \pm 0.05$ & $1.00 \pm 0.05$ \\
\hline
\end{tabular}

$a, b=$ values with different superscripts within rows are significantly different $(p<0.05)$

Some scientists (Chandler et al., 1976; Buttery and Foulds, 1985; Lundquist et al., 1985b) explain the increase of milk fat production by the beneficial effect exerted by bypass methionine on the activity of rumen microbes. According to other researchers (Chamberlain and Thomas, 1982; Huber et al., 1984), higher milk fat production may be due to the availability of more methionine for intermediary metabolism, which positively influences liver activity and fat metabolism.

The beneficial effects of bypass methionine can be explained by different reasons. The first of these should be the classical amino acid effect, namely that the feeding of methionine enhances protein synthesis. Beyond that, some scientists have established that methionine addition has a beneficial effect on the activity of rumen microbes (Lundquist et al., 1985a; Patterson and Kung, 1988), increases the number of protozoa (Vuyst et al., 1975; Günther and Hagena, 1987). Methionine also has a positive effect on lipoprotein metabolism (Koch, 1984; Doil, 1985).

It can be concluded that the bypass methionine product Mepron M 85 has satisfactory ruminal stability and, as a result of its feeding, the quantity of methionine getting into the small intestine increases. As the methionine supply of cows improves, milk and milk fat production increases significantly in the first third of lactation. 


\section{Acknowledgement}

The authors express their special thanks to Degussa AG for supporting the experiments.

\section{References}

ARC (1980): The Nutrient Requirements of Ruminant Livestock. Commonwealth Agricultural Bureaux, Farnham Royal, Slough, U. K.

Broderick, G. A., Satter, L. D. and Harper, A. E. (1974): Use of plasma amino acid concentration to identify limiting amino acid for milk production. J. Dairy Sci. 57, 1015-1022.

Burgstaller, G., Zywczok, H., Morgalle, H. and Lindner, J. P. (1983a): Zum Einsatz von geschütztem Sojaprotein und N-Hydroxymethyl-DL-Methionin-Calcium in der Fütterung von hochleistenden Milchkühen 1. Mitteilung. Züchtungskunde 55, 275-288.

Burgstaller, G., Schaller, Chr. and Zywczok, H. (1983b): Zum Einsatz von geschütztem Sojaprotein und N-Hydroxymethyl-DL-Methionin in der Fütterung von hochleistenden Milchkühen. 2. Mitteilung. Züchtungskunde 55, 289-298.

Buttery, P. J. and Foulds, A. N. (1985): Amino acid requirements of ruminants. In: Haresign, V. and Cole, D. J. A. (eds) Recent Advances in Animal Nutrition. Butterworths, London.

Chamberlain, D. G. and Thomas, P. C. (1982): Effect of intravenous supplements of L-methionine on milk yield and composition in cows given silage-cereal rations. J. Dairy Res. 49, 25-28.

Chandler, P. T., Brown, C. A., Johnston, R. P., Macleod, G. K., McCarthy, R. D., Mos, B. R., Rakes, A. H. and Satter, L. D. (1976): Protein and methionine hydroxy analog for dairy cows. J. Dairy Sci. 59, 1897-1909.

Clark, J. H. (1975): Lactational response to postruminal administration of protein and amino acids. J. Dairy Sci. 58, 1178-1196.

Daugaard, J. (1978): Investigation on methionine supplement to lactating cows. Ph.D. Thesis, Royal Veterinary and Agricultural University, Copenhagen.

Degussa Analytik/Analysis (1986): Hanau.

Doil, G. (1985): Einfluss von N-Hydroxymethyl-DL-Methionine-Ca auf Milchleistung und ketoserelevante Blutparameter bei bedarfsgerecht und restriktiv gefütterten Milchkühen. Thesis, Veterinary College, Hannover.

Fischer, L. J. (1972): Response of lactating cows to the intravenous infusion of amino acids. Can. J. Anim. Sci. 52, 377-384.

Günther, K. D. and Hagena, F. (1987): Der Einfluss eines geschützten Methionin-Supplementes auf die Milchleistung. Kraftfutter 70, 128-134.

Hagemeister, H. (1984): Methoden zur Messung der Schutzrate verschiedener Methioninformen. In: Aktuelle Themen zur Tierernährung und Veredlungswirtschaft. Lohmann Tierernährung, Cuxhaven. pp. 89-95.

Hagemeister, H. and Kaufmann, W. (1979): Probleme der Eiweissversorgung von Hochleistungskühen. In: Aktuelle Themen zur Tierernährung und Veredlungswirtschaft. Lohmann Tierernährung, Cuxhaven. pp. 67-80.

Hagena, F. (1985): Untersuchungen zum Einfluss eines „geschützten“ Methionin Supplements auf verschiedene Leistungmerkmale bei Milchkühen. Thesis, Agric. University Göttingen.

Huber, J. T., Emery, R. S., Bergen, W. G., Liesman, J. S., Kung, L., King, K. J., Gardner, R. W. and Checketts, M. (1984): Influences of methionine hydroxy analog on milk fat production, blood serum lipids and plasma amino acids. J. Dairy Sci. 67, 2525-2531.

Illg, D. J., Sommerfeld, D. J. and Schingoethe, D. J. (1987): Lactational and systematic responses to the supplementation of protected methionine in soybean meal diets. J. Dairy Sci. 70, 620-629. 
Journet, M. and Hoden, A. (1980): Utilisation of methionine supplementation to lactating cows in early lactation. Institut National de Recherche Agricola, Paris.

Kaufmann, W. and Lüpping, W. (1979): Zum Einfluss von Protected Protein und HMM-Ca auf die Leistung von Milchkühen. Z. Tierphysiol., Tierernähr. Futtermittelkde 41, 202-217.

Kaufmann, W. and Lüpping, W. (1982): Protected proteins and protected amino acids for ruminants In: Miller, E. L., Pike, J. H. and Van Es, A. J. H. (eds): Protein Contribution of Feedstuffs for Ruminants. Butterworths, London. pp. 36-75.

Koch, F. (1984): Aminosäuren in der Wiederkänerfütterung. Swiss Vet. 1, 27-29.

Koch, F. and Tanner, H. (1981): Zum Einfluss von oral verabreichten geschützten Methionin auf den Plasmaaminosäuregehalt. Landw. Forschung, Sonderheft 38, 464-476.

Küther, K. (1982): Erkenntnisse zum geschützten Methionin. In: Aktuelle Themen zur Tierernährung und Veredlungswirtschaft. Lohmann Tierernährung, Cuxhaven. pp. 51-62.

Langar, P. N., Buttery, P. J. and Lewis, D. (1978): N-stearoyl-DL-methionine, a protected methionine source for ruminants. J. Food Sci. Agric. 29, 808-814.

Leibetseder, J., Steinberger, H. and Steinberger, A. (1985): Einfluss von geschütztem Methionin auf einige Leistungsparameter von Milchkühen. Wiener tierärtzl. Monatsschr. 72, 377-386.

Lettner, F. (1983): Einsatz von geschütztem Methionin in der Milchviehfütterung. Der Förderungsdienst 11, 228-231.

Lundquist, R. G., Otterby, D. E. and Linn, J. G. (1985a): Influence of three concentrations of DL-methionine or methionine hydroxy analog on milk yield and milk composition. J. Dairy Sci. 68, 3050-3054.

Lundquist, R. G., Stern, M. D., Otterby, D. E. and Linn, J. G. (1985b): Influence of methionine hydroxy ana$\log$ and DL-methionine on rumen protozoa and volatile fatty acids. J. Dairy Sci. 68, 3055-3058.

Mate, J. (1985): Extra protection. Dairy Farmer 12, 36-41.

Patterson, J. A. and Kung, L. Jr. (1988): Metabolism of DL-methionine and methionine analogs by rumen microorganisms. J. Dairy Sci. 71, 3292-3301.

Rogers, G. L. and McLeay, L. M. (1977): Responses of lactating cows to abomasal infusion of casein, methionine and glucose. Proc. N. Z. Soc. Anim. Prod. 37, 48-49.

Schelling, G. T., Chandler, J. E. and Scott, G. C. (1973): Postruminal supplemental methionine infusion to sheep feed high quality diets. J. Anim. Sci. 37, 1034-1039.

Schiemann, R. (1981): Milchbildung. In: Gebhardt, G. (ed.) Tierernährung. VEB Deutsch. Landwirtschaftsverlag, Berlin Kapitel 9, 249-274.

Schmidt, J., Cenkvári, É. and Kaszás, I. (1987): Use of protected methionine in the feeding of cows (in Hungarian). Állattenyésztés és Takarmányozás 37, 13-19.

Schmidt, J., Várhegyi, I., Várhegyi, J. and Cenkvári, É. (1998): Proposal for a new Hungarian protein evaluation system to be introduced in ruminant feeding (in Hungarian). Állattenyésztés és Takarmányozás 47, 165-178.

Schwab, C. G., Satter, L. D. and Clay, A. B. (1976): Response of lactating dairy cows to abomasal infusion of amino acids. J. Dairy Sci. 59, 1254-1269.

Spiekers, H. (1988): Untersuchungen an Milchkühen über die Wirkung einer Zulage von „geschütztem“ Methionin auf Milchleistung und einige Kenngrössen im Blut. Thesis, Agric. University Bonn.

Sprondly, R. (1981): Feeding experiment with coated methionine to lactating dairy cows. In: Küther, K. (ed.) (1982): Erkenntnisse zum geschützten Methionin. Aktuelle Themen zur Tierernährung und Veredlungswirtschaft. Lohmann Tierernährung, Cuxhaven. pp. 51-62.

Vuyst, A., Vanbelle, M., Joassart, J. M. and Baguette, A. (1975): The effect of methionine hydroxy analog supplementation of the diet on the concentration of ciliate protozoa in the rumen of sheep. Z. Tierphysiol., Tierernähr. Futtermittelkde 35, 316-321.

Yang, C. M. J., Schingoethe, D. J. and Casper, D. P. (1986): Protected methionine and heat-treated soybean meal for high producing dairy cows. J. Dairy Sci. 69, 2348-2357. 